\title{
Ethanol production from cassava using a newly isolated thermotolerant yeast strain
}

\author{
Chutima Kaewkrajay $^{\mathrm{a}, *}$, Tida Dethoup ${ }^{\mathrm{b}}$, Savitree Limtong ${ }^{\mathrm{c}}$ \\ ${ }^{a}$ Faculty of Science and Technology, Phranakhon Si Ayutthaya Rajabhat University, \\ Ayutthaya 13000 Thailand \\ b Faculty of Agriculture, Kasetsart University, Bangkok 10900 Thailand \\ c Faculty of Science, Kasetsart University, Bangkok 10900 Thailand \\ *Corresponding author, e-mail: kchutima@aru.ac.th, pretty_yeast@yahoo.com
}

Received 23 Sep 2013

Accepted 12 May 2014

\begin{abstract}
Efficient ethanol production using thermotolerant yeast strains was carried out with a newly isolated yeast strain called 267. Strains were isolated with an enriched technique consisting of a blackstrap molasses medium supplemented with $40 \mathrm{ml} / \mathrm{l}$ of ethanol at $25-28^{\circ} \mathrm{C}$. The results revealed that 33 strains produced ethanol at $45^{\circ} \mathrm{C}$ in the cassava starch hydrolysate medium, $\mathrm{pH} 4.5$, which was composed of $180 \mathrm{~g} / \mathrm{l}$ reducing sugar and $0.5 \mathrm{~g} / 1\left(\mathrm{NH}_{4}\right)_{2} \mathrm{SO}_{4}$, with a shaking speed of $120 \mathrm{rpm}$. The highest ethanol concentrations (26.2,26.2, 23.6, and $22.5 \mathrm{~g} / \mathrm{l}$ ) were found from Pichia kudriavzevii strains PBB511-1, TM512-2, CPY514-1, and TG514-2, respectively. The yeast strain PBB511-1, which produced the highest ethanol yield, was selected for ethanol production in the shaking flask at $45^{\circ} \mathrm{C}$. Ethanol production reached the highest level after $36 \mathrm{~h}$ in a medium composed of $180 \mathrm{~g} / \mathrm{l}$ reducing sugar, $0.5 \mathrm{~g} / \mathrm{l}\left(\mathrm{NH}_{4}\right)_{2} \mathrm{SO}_{4}, 0.5 \mathrm{~g} / \mathrm{KH}_{2} \mathrm{PO}_{4}, 0.5 \mathrm{~g} / 1 \mathrm{MgSO}_{4} \cdot 7 \mathrm{H}_{2} \mathrm{O}$, and $1 \mathrm{~g} / \mathrm{l}$ yeast extract. It produced $37 \mathrm{~g} / \mathrm{l}$ ethanol, with a productivity of $1.03(\mathrm{~g} / \mathrm{l}) / \mathrm{h}$ and a yield of $40 \%$ of the theoretical yield. The ethanol production by batch fermentation at $45^{\circ} \mathrm{C}$ was performed in a $7-1$ jar fermenter with an agitation speed of $300 \mathrm{rpm}$ and an aeration rate of $0.2 \mathrm{vvm}$ throughout the fermentation. The results implied that the maximum ethanol concentration was $42.4 \mathrm{~g} / \mathrm{l}$ after $48 \mathrm{~h}$, at a rate of $0.88(\mathrm{~g} / \mathrm{l}) / \mathrm{h}$ and a yield of $46 \%$ of the theoretical yield.
\end{abstract}

KEYWORDS: Pichia kudriavzevii, high temperature, isolation, identification

\section{INTRODUCTION}

Due to the current crisis of increasing petroleum fuel prices as well as problems concerning global warming, several countries are seeking alternative energy sources such as ethanol ${ }^{1-4}$. Ethanol is a pure form of energy that has minimal impact to the environment.

For ethanol production in Thailand, a number of raw materials are used such as molasses and cassava $^{5,6}$. Cassava (Manihot esculenta), in particular, is considered a main industrial crop. In addition, cassava can grow well in soil with poor fertility. Apart from that, cassava can endure drought conditions, and can also withstand severe acidic soil conditions. Cassava does not need substantial care, has high yield per surface, and has a low cost of production compared with other types of crops ${ }^{7,8}$. The use of cassava as a raw material to produce ethanol can therefore be a mean of financially assisting cassava farmers.

Thailand is a tropical country, and the average temperature during daytime is considerably high, particularly in the summer. As a result of heat circulation during ethanol fermentation by yeast, the temperature in the fermentation tanks increases to levels that in- hibit yeast growth, decrease survival rate, and impair ethanol fermentation. Hence, to ferment ethanol, it is essential to use a cooling system that ventilates the heat generated from yeast activity ${ }^{9-11}$. In doing so, the cost of ethanol production inevitably rises.

This study searches for new thermotolerant yeast strains which can produce ethanol at high temperatures, using cassava as the feedstock. Through a combination of cheap substrate and an effective ethanolproducing yeast, this alternative will be a viable option for a fuel source.

\section{MATERIALS AND METHODS}

\section{Preparation of materials}

Cassavas were washed in fresh water to get rid of sand, then peeled and chipped. The wet chips were sun-dried for 2 days and processed with a blender. The flour was sieved through an 80 mesh screen, and then prepared for analysis of moisture following the Thai Industrial Standards TISI No. 52 number 6.4. The total starch in flour was analysed by modifying methods of $\mathrm{AOAC}^{12}$ and $\mathrm{AACC}^{13}$. This flour was used as the substrate. 
The slurry of cassava flour $(30 \% \mathrm{w} / \mathrm{v})$ prepared in distilled water was adjusted to an initial $\mathrm{pH}$ of 6.0 before being liquefied by $\alpha$-amylase (Alphamalt VC 5000; 5250 units/g) at a concentration of $1 \mathrm{~g}$ per $\mathrm{kg}$ of dry starch and temperature range between 95 and $100^{\circ} \mathrm{C}$ for $2 \mathrm{~h}$ with agitation. The $\mathrm{CaCl}_{2}$ at the concentration of $1 \mathrm{~g}$ per $\mathrm{kg}$ of dry starch was added to the slurry for enzyme stabilization. After $2 \mathrm{~h}$, the temperature of the fluid dextrin was reduced to $65^{\circ} \mathrm{C}$, the $\mathrm{pH}$ was adjusted to 4.0 with $1 \mathrm{M} \mathrm{HCl}$ and the saccharification was then completed by loading amyloglucosidase (AGU 750 units/g) at a concentration of $0.45 \mathrm{~g}$ per $\mathrm{kg}$ of dry starch. The solution was incubated at $65^{\circ} \mathrm{C}$ for $24 \mathrm{~h}$ under agitation on a water bath shaker. After the saccharification was completed, the reaction was stopped by boiling for $20 \mathrm{~min}$. Aliquots were sampled for analysis of reducing sugar concentration by Nelson-Somogyi method ${ }^{14}$.

\section{Isolation and selection of thermotolerant yeast strains}

Yeasts were isolated from the soil in the sugarcane, cassava and pineapple plantations in five provinces of Thailand, namely Chachoengsao, Chonburi, Prachinburi, Ratchaburi, and Kanchanaburi. The isolation was done using the diluted sugarcane blackstrap molasses medium containing $5 \mathrm{~g} / \mathrm{l}$ reducing sugar, $0.5 \mathrm{~g} / \mathrm{l}\left(\mathrm{NH}_{4}\right)_{2} \mathrm{SO}_{4}$ and an initial $\mathrm{pH}$ of 4.5 with a shaking speed of $160 \mathrm{rpm}$ for $72 \mathrm{~h}$ at $25-30^{\circ} \mathrm{C}$. The cultures were purified by cross streaking on agar plates containing the same medium and then were incubated at $25-30{ }^{\circ} \mathrm{C}$ for $2-3$ days. The purified cultures were kept on YPD agar (yeast extract $5 \mathrm{~g} / \mathrm{l}$, peptone $10 \mathrm{~g} / \mathrm{l}$, dextrose $10 \mathrm{~g} / \mathrm{l}$ and agar $20 \mathrm{~g} / \mathrm{l}$ ) slant and maintained at $4{ }^{\circ} \mathrm{C}$.

The selection of thermotolerant yeast strains was performed in $5 \mathrm{ml}$ YPD broth supplemented with $40 \mathrm{ml} / \mathrm{l}$ of ethanol. Ethanol was obtained in $16 \times 100 \mathrm{ml}$ test tubes, which were soaked in a water bath at various temperatures $\left(37,40,45\right.$, and $\left.50^{\circ} \mathrm{C}\right)$. The yeast strains could be grown at a temperature range $37-50{ }^{\circ} \mathrm{C}$. They were then examined in cassava starch hydrolysate medium containing $20 \mathrm{~g} / \mathrm{l}$ reducing sugar, $0.5 \mathrm{~g} / \mathrm{l}\left(\mathrm{NH}_{4}\right)_{2} \mathrm{SO}_{4}$, having an initial $\mathrm{pH}$ of 4.5 and supplemented with $40 \mathrm{ml} / \mathrm{l}$ of ethanol. The successful cultures were kept at the $4{ }^{\circ} \mathrm{C}$ for further screening.

\section{Screening of thermotolerant yeast strains for ethanol production at $45^{\circ} \mathrm{C}$}

The yeast strains could be grown at $45^{\circ} \mathrm{C}$ in the cassava starch hydrolysate medium supplemented with $40 \mathrm{ml} / \mathrm{l}$ of ethanol. The yeasts were screened in the cassava starch hydrolysate medium composed of $180 \mathrm{~g} / \mathrm{l}$ reducing sugar, $0.5 \mathrm{~g} / 1\left(\mathrm{NH}_{4}\right)_{2} \mathrm{SO}_{4}$, with an initial $\mathrm{pH} 4.5$. Inocula were prepared by transferring 1 full loop of the yeast cells to $20 \mathrm{~g} / \mathrm{l}$ reducing sugar of cassava starch hydrolysate medium containing $0.5 \mathrm{~g} / \mathrm{l}$ $\left(\mathrm{NH}_{4}\right)_{2} \mathrm{SO}_{4}, \mathrm{pH} 4.5$, which was obtained in a $125-\mathrm{ml}$ Erlenmeyer flask containing $50 \mathrm{ml}$ of medium and a shaking speed of $160 \mathrm{rpm}$ at $25-30^{\circ} \mathrm{C}$ for $24 \mathrm{~h}$. The inocula were transferred to the $5 \%$ rate of the screening medium and were cultivated at $45^{\circ} \mathrm{C}$ for $72 \mathrm{~h}$ at the shaking speed of $120 \mathrm{rpm}$. The slop was sampled for the analysis of the ethanol concentration.

\section{Identification of thermotolerant yeast strains}

The selected yeast strains were morphologically and physiologically characterized following Ref. 15. Yeast strains growing on YM agar for $24 \mathrm{~h}$ were morphologically studied in terms of cells, both true mycelium and pseudo-mycelium formation by using the Dalmau plate technique. Ballistospores and ascospores formation as well as the growth examination of yeast strains were undertaken at various temperatures: $30,35,37,40,45$, and $50^{\circ} \mathrm{C}$.

The yeast strains were also identified by the molecular taxonomy following the method of Kurtzman and Robnette ${ }^{16}$. Briefly, the yeast cells were suspended in sterile distilled water and kept in a frosted container, then heated for $10 \mathrm{~min}$ at boiling point and put back in the same frosted container.

DNA was extracted and used to amplify $26 \mathrm{~S}$ rDNA by PCR technique. The PCR product was purified with a PCR purification kit and purified again by the ethanol/EDTA method before it was calculated for base taxonomy of D1/D2 domain of a large subunit of ribosomal DNA (26S rDNA) with a DNA sequencer. The obtained nucleotides were compared for similarities in the GenBank database.

\section{Optimization of ethanol fermentation in a shaking flask}

The fermentation medium in a 500-ml Erlenmeyer flask was performed in triplicate using $200 \mathrm{ml}$ of basal cassava starch hydrolysate medium, composed of different reducing sugar concentrations of 160,180 , and $200 \mathrm{~g} / \mathrm{l}$ with added $0.5 \mathrm{~g} / \mathrm{l}\left(\mathrm{NH}_{4}\right)_{2} \mathrm{SO}_{4}$; initial $\mathrm{pH}$ was adjusted to 4.5 with $1 \mathrm{M} \mathrm{HCl}$ and $1 \mathrm{M} \mathrm{NaOH}$. Inoculum size was $5 \%$. The flasks were incubated at $45^{\circ} \mathrm{C}$ with the shaking speed of $120 \mathrm{rpm}$. Samples were taken every 6-12 $\mathrm{h}$ for a period of $72 \mathrm{~h}$. The growth, as well as sugar and ethanol concentration, was measured.

The other nutrient compositions such as nitrogen source, phosphorus source, magnesium source, and 
yeast extract were also studied. The culture medium was supplemented with 0.5 or $1 \mathrm{~g} / \mathrm{l}$ of $\left(\mathrm{NH}_{4}\right)_{2} \mathrm{SO}_{4}$, $\mathrm{KH}_{2} \mathrm{PO}_{4}$, or $\mathrm{MgSO}_{4}$ and the results compared to that without supplementation. Finally, the yeast extract was supplemented at $1,2 \mathrm{~g} / \mathrm{l}$, or without. The best ethanol fermentation conditions were selected for further study.

\section{Ethanol fermentation in a fermenter}

The inoculum media placed in $20 \mathrm{~g} / 1$ reducing sugar, $0.5 \mathrm{~g} / \mathrm{l}\left(\mathrm{NH}_{4}\right)_{2} \mathrm{SO}_{4}, \mathrm{pH} 4.5$ was autoclaved at $121^{\circ} \mathrm{C}$ for $15 \mathrm{~min}$. A loopful of yeast cells was added into $100 \mathrm{ml}$ inoculum media in a 250-ml Erlenmeyer flask and the culture was shaken at a speed of $160 \mathrm{rpm}$ at room temperature for $24 \mathrm{~h}$.

The composition of the nutrients in the main media for fermentation was selected from the optimized condition in the shaking flask. The main medium was autoclaved at $121^{\circ} \mathrm{C}$ for $20 \mathrm{~min}$ and then $200 \mathrm{ml}$ of the inoculum was transferred $(5 \% \mathrm{v} / \mathrm{v})$ into 41 of main media and cultivated at $45^{\circ} \mathrm{C}$ for $72 \mathrm{~h}$.

Batch fermentation was carried out in a 71 jar fermenter with 41 of working volume. The fermentation was performed in duplicate at $45^{\circ} \mathrm{C}$ for $72 \mathrm{~h}$ with agitation speed of $300 \mathrm{rpm}$ and aeration rate of $0.2 \mathrm{vvm}$ throughout the fermentation ${ }^{9}$. The slop was sampled for monitoring the growth, sugar consumption, and ethanol concentration every 4-12 h for a period of $72 \mathrm{~h}$.

\section{Analytical methods}

The growth of yeast was monitored by measuring the optical density at the wavelength of $660 \mathrm{~nm}$ using a spectrophotometer (Shimadzu; UV-pharmaspec 1700). After washing the yeast cells with $0.1 \mathrm{M} \mathrm{HCl}$ twice, they were centrifuged at $4000 \mathrm{rpm}$ for $5 \mathrm{~min}$. The cell pellet was then resuspended in $0.1 \mathrm{M}$ EDTA $\mathrm{pH} 7$.

The ethanol concentration was analysed by gas chromatography using the Varian Star 3600 GC apparatus equipped with an autosampler 8200 injector, a flame ionization detector and a capillary DB-WAX column coated at $70{ }^{\circ} \mathrm{C}$. The injector and the detector were maintained at $200^{\circ} \mathrm{C}$. Nitrogen gas was used for carrier samples with flow rate $4 \mathrm{ml} / \mathrm{min}$. The internal standard used was $n$-propanol ${ }^{17}$. The ethanol concentration was calculated from the ratio of area of ethanol and propanol and then compared with the standard. The ethanol productivity was calculated from the final ethanol concentration subtracting the initial ethanol concentration, and dividing by the fermentation time. The fermentation yield depended on the initial sugar concentration $^{18}$.
The sugar concentration was measured using Somogyi-Nelson method ${ }^{14}$. High sugar concentration was diluted with distilled water until the optical density at the wavelength of $520 \mathrm{~nm}$ was in the range of 0.1-1.0. The sugar concentration of the samples was compared with the glucose standard.

\section{RESULTS}

\section{Isolation and selection of thermotolerant yeast strains}

In this study, thermotolerant yeast strains were isolated from soil samples that are associated with sugarcane, cassava, and pineapple fields. The samples were then enriched in the diluted sugarcane blackstrap molasses supplemented with $40 \mathrm{ml} / \mathrm{l}$ of ethanol and incubated on a rotary shaker at $25-28^{\circ} \mathrm{C}$ for $72 \mathrm{~h}$. A total of 267 yeast strains obtained were used to determine the growth at elevated temperatures by using the YM broth as a substrate. Among these, 2 strains were capable of growing at $50{ }^{\circ} \mathrm{C}$ and 169 strains survived and grew at a temperature of $45^{\circ} \mathrm{C}$, while 96 strains could only endure a maximum of $40^{\circ} \mathrm{C}$. The yeast strains that were capable of growing at $45^{\circ} \mathrm{C}$ were cultivated in the basal cassava medium containing $20 \mathrm{~g} / \mathrm{l}$ reducing sugar, $0.5 \mathrm{~g} / 1\left(\mathrm{NH}_{4}\right)_{2} \mathrm{SO}_{4}$ and the initial $\mathrm{pH}$ of 4.5 , then $40 \mathrm{ml} / 1$ of ethanol was added in the medium and incubated at $45^{\circ} \mathrm{C}$ in a water bath. The results revealed that 33 strains grew satisfactorily even at $45^{\circ} \mathrm{C}$.

\section{Screening of thermotolerant yeast strain by ethanol production at $45^{\circ} \mathrm{C}$}

The ethanol production of 33 strains was performed in the basal cassava medium containing $180 \mathrm{~g} / \mathrm{l}$ reducing sugar, $0.5 \mathrm{~g} / \mathrm{l}\left(\mathrm{NH}_{4}\right)_{2} \mathrm{SO}_{4}$ and an initial $\mathrm{pH}$ of 4.5 by cultivation at $45^{\circ} \mathrm{C}$ for $72 \mathrm{~h}$. All of them were able to produce ethanol at various concentrations (Table 1).

The 4 strains that produced ethanol higher than 20 g/l were PBB511-1, TM512-2, CPY514-1, and TG514-2. Among these, PBB511-1 produced ethanol at a slightly greater concentration than TM512-2 (Table 1).

\section{Identification of the thermotolerant yeast strains}

The strains PBB511-1, TM512-2, CPY514-1, and TG514-2 were identified morphologically and physiologically following a taxonomic key ${ }^{15}$. The colonies of the 4 yeast strains growing on YM agar turned out murky white, low embossed, and with margins smooth to lobed. The growth in the YM broth at room temperature showed sediments of cells at the bottom of the tube. Moreover, the colour of the media became 
Table 1 Ethanol concentration of thermotolerant yeast strains cultured in shaking flask at $45^{\circ} \mathrm{C}$.

\begin{tabular}{lclccc}
\hline Strains & EtOH $(\mathrm{g} / \mathrm{l})$ & Strains & EtOH $(\mathrm{g} / \mathrm{l})$ & Strains & EtOH $(\mathrm{g} / \mathrm{l})$ \\
\hline CPY514-1 & 23.59 & CSK516-3 & 6.98 & PR516-2 & 15.33 \\
CPK514-1 & 15.27 & CSK5110-2 & 4.67 & TM512-1 & 16.22 \\
CPK514-2 & 13.20 & CSK5110-3 & 19.34 & TM512-2 & 26.20 \\
CPK514-3 & 14.26 & BB516-1 & 4.28 & TG513-1 & 2.59 \\
CPK514-4 & 14.73 & BB516-2 & 14.17 & TG513-2 & 12.23 \\
CPK518-3 & 12.60 & BB519-1 & 2.95 & TG513-3 & 4.44 \\
CSK511-1 & 19.82 & BB519-2 & 3.41 & TG514-1 & 13.89 \\
CSK511-2 & 17.22 & BB519-3 & 4.17 & TG514-2 & 22.51 \\
CSK511-3 & 16.98 & PBB511-1 & 26.22 & TG518-3 & 3.58 \\
CSK516-1 & 7.19 & PBB511-2 & 15.02 & PM515-1 & 8.62 \\
CSK516-2 & 7.47 & PR516-1 & 14.48 & PM515-2 & 16.28 \\
\hline
\end{tabular}

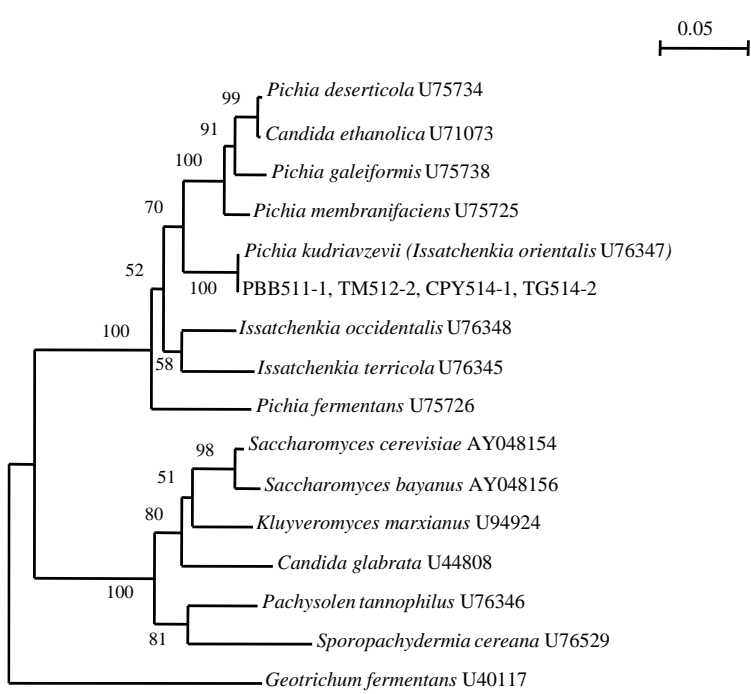

Fig. 1 Phylogenetic tree of PBB511-1, TM512-2, CPY514-1, and TG514-2.

faded with a thin film formed at the surface. When the cells were studied under the light microscope, they were ovoid to elongated in shape. A pseudo-mycelium was observed with moderately branched appearance under the coverglass after 7 days at room temperature. No ascospores or ballistospores were found. The results also showed that the 4 yeast strains could grow at a maximum temperature of $45^{\circ} \mathrm{C}$.

The molecular taxonomy of the strains was done using the nucleotide sequences of D1/D2 domain of the large subunit ribosomal DNA. Their sequences were the same as that of Pichia kudriavzevii (Issatchenkia orientalis). Hence the strains PBB511-1, TM512-2, CPY514-1, and TG514-2 were identified as $P$. kudriavzevii. The phylogenetic tree of the strains is shown in Fig. 1.

\section{Optimization of ethanol fermentation in shaking} flask cultivation at $45^{\circ} \mathrm{C}$

The strain PBB511-1, found to produce the greatest ethanol concentration, was chosen for optimization in various conditions. The effect of sugar concentration on ethanol fermentation of this strain was investigated in a basal cassava media composed of 160,180 , or $200 \mathrm{~g} / \mathrm{l}$ reducing sugar. The results revealed that the appropriate basal cassava medium for ethanol production was the medium composed of $180 \mathrm{~g} / \mathrm{l}$ reducing sugar (Fig. 2a). At $48 \mathrm{~h}$, the ethanol concentration was $23.9 \mathrm{~g} / \mathrm{l}$, the productivity $0.5(\mathrm{~g} / \mathrm{l}) / \mathrm{h}$, and the yield $26 \%$ of the theoretical yield. The increase of sugar concentration to $200 \mathrm{~g} / \mathrm{l}$ reducing sugar had not been accrued for the ethanol production. At $48 \mathrm{~h}$, the ethanol concentration was $23.2 \mathrm{~g} / \mathrm{l}$, the productivity $0.48(\mathrm{~g} / \mathrm{l}) / \mathrm{h}$, and the yield $23 \%$ of the theoretical yield. The decrease of ethanol concentration involved several factors such as high osmotic pressure conditions and high temperatures ${ }^{19}$. On the other hand, the decrease of sugar concentration to $160 \mathrm{~g} / \mathrm{l}$ reduced the ethanol concentration. The ethanol produced was $15.2 \mathrm{~g} / \mathrm{l}$, with a productivity of $0.32(\mathrm{~g} / \mathrm{l}) / \mathrm{h}$, and a yield of $19 \%$ of theoretical yield (Table 2, Fig. 3a). The decrease of sugar concentration was probably due to the fact that most of the reducing sugar was used for growth. Hence there was less reducing sugar available to be transformed into ethanol.

The effect of $\left(\mathrm{NH}_{4}\right)_{2} \mathrm{SO}_{4}$ as the $\mathrm{N}$-source was examined at concentrations of $0,0.5$, and $1.0 \mathrm{~g} / \mathrm{l}$ in a basal cassava medium composed of $180 \mathrm{~g} / \mathrm{l}$ reducing sugar. A greater ethanol production was obtained in the medium containing nitrogen at $0.5 \mathrm{~g} / \mathrm{l}$ (Fig. 2b). At $48 \mathrm{~h}$, the ethanol produced was $25.8 \mathrm{~g} / \mathrm{l}$ with a productivity of $0.54(\mathrm{~g} / \mathrm{l}) / \mathrm{h}$ and a yield of $28 \%$ of theoretical yield. The fermentation without $\mathrm{N}$-source produced ethanol at $14.0 \mathrm{~g} / \mathrm{l}$, a productivity of $0.29(\mathrm{~g} / \mathrm{l}) / \mathrm{h}$ and a yield of $15 \%$ of theoretical yield, while the fermen- 

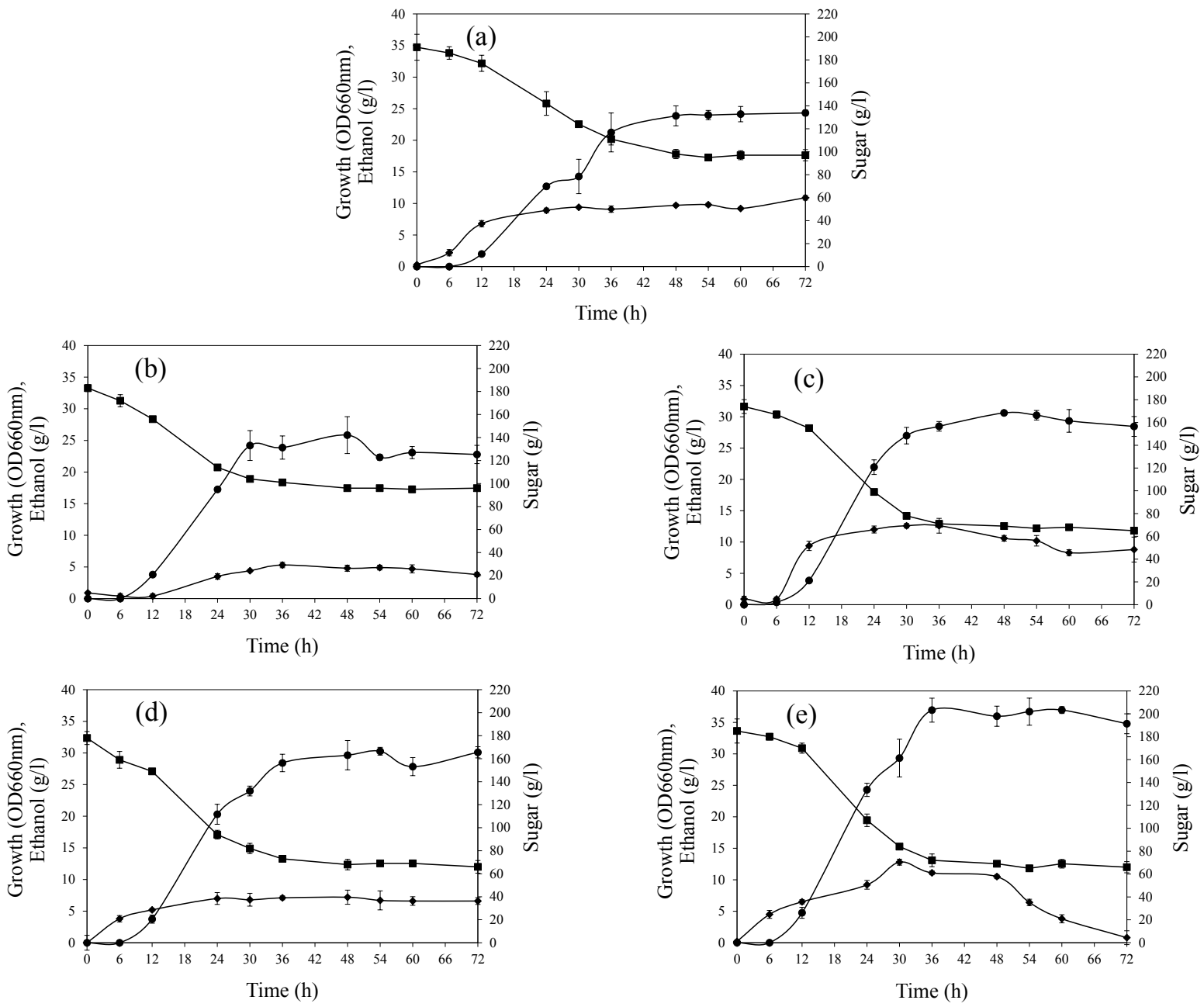

Fig. 2 Growth (diamonds), ethanol production (circles), and sugar consumption (squares) of yeast strain PBB511-1 in cassava medium composed of (a) $180 \mathrm{~g} / \mathrm{l}$ reducing sugar, (b) $180 \mathrm{~g} / \mathrm{l}$ reducing sugar, $0.5 \mathrm{~g} / \mathrm{l}\left(\mathrm{NH}_{4}\right)_{2} \mathrm{SO}_{4}$, (c) $180 \mathrm{~g} / \mathrm{l}$ reducing sugar, $0.5 \mathrm{~g} / \mathrm{l}\left(\mathrm{NH}_{4}\right)_{2} \mathrm{SO}_{4}, 0.5 \mathrm{~g} / 1 \mathrm{KH}_{2} \mathrm{PO}_{4}$, (d) $180 \mathrm{~g} / \mathrm{l}$ reducing sugar, $0.5 \mathrm{~g} / 1\left(\mathrm{NH}_{4}\right)_{2} \mathrm{SO}_{4}, 0.5 \mathrm{~g} / 1 \mathrm{KH}_{2} \mathrm{PO}_{4}, 0.5 \mathrm{~g} / \mathrm{l}$ $\mathrm{MgSO}_{4} \cdot 7 \mathrm{H}_{2} \mathrm{O}$, and (e) $180 \mathrm{~g} / \mathrm{l}$ reducing sugar, $0.5 \mathrm{~g} / \mathrm{l}\left(\mathrm{NH}_{4}\right)_{2} \mathrm{SO}_{4}, 0.5 \mathrm{~g} / \mathrm{KH}_{2} \mathrm{PO}_{4}, 0.5 \mathrm{~g} / \mathrm{l} \mathrm{MgSO} \mathrm{H}_{4} \cdot 7 \mathrm{H}_{2} \mathrm{O}, 1 \mathrm{~g} / \mathrm{l}$ yeast extract. All cultures had initial $\mathrm{pH} 4.5$ and were agitated at $120 \mathrm{rpm}$ at $45^{\circ} \mathrm{C}$.

tation in the presence of $1.0 \mathrm{~g} / \mathrm{l}\left(\mathrm{NH}_{4}\right)_{2} \mathrm{SO}_{4}$ produced ethanol at $18.4 \mathrm{~g} / \mathrm{l}$, with a productivity of $0.38(\mathrm{~g} / \mathrm{l}) / \mathrm{h}$ and a yield of $20 \%$ of theoretical yield (Table 2, Fig. 3b). Nitrogen is important to the yeast cells and can affect their growth rate. A decrease or increase in nitrogen can result in a slow growth rate for yeast cells $^{20,21}$. In the first $48 \mathrm{~h}$, the growth of yeast cells without $\mathrm{N}$-source was very slow $\left(\mathrm{OD}_{660} \mathrm{~nm}=4.4\right)$, while with 0.5 and $1.0 \mathrm{~g} / \mathrm{l}$ of $\left(\mathrm{NH}_{4}\right)_{2} \mathrm{SO}_{4}$ the yeast cells had growing rates that was almost the same at $\mathrm{OD}_{660 \mathrm{~nm}}$ of 4.8 and 5.5, respectively. In the case of sugar, the fermentation with an addition of $0.5 \mathrm{~g} / \mathrm{l}$ $\left(\mathrm{NH}_{4}\right)_{2} \mathrm{SO}_{4}$, sugar had a dramatic decrease in the first $24 \mathrm{~h}$, and remained at $96 \mathrm{~g} / \mathrm{l}$ as it approached $72 \mathrm{~h}$ of fermentation. On the other hand, the fermentation with an added $1.0 \mathrm{~g} / \mathrm{l}\left(\mathrm{NH}_{4}\right)_{2} \mathrm{SO}_{4}$ and no $\mathrm{N}$-source had remaining sugar concentrations of $105 \mathrm{~g} / \mathrm{l}$ and $116 \mathrm{~g} / \mathrm{l}$, respectively.

The influence of the concentration of phosphorus on ethanol production was studied as follows: concentration of sugar $180 \mathrm{~g} / \mathrm{l}, 0.5 \mathrm{~g} / \mathrm{l}\left(\mathrm{NH}_{4}\right)_{2} \mathrm{SO}_{4}$, with a P-source in $\mathrm{KH}_{2} \mathrm{PO}_{4}$ concentrated format of $0,0.5$, and $1.0 \mathrm{~g} / \mathrm{l}$. The study within $48 \mathrm{~h}$ revealed that the concentration of $0.5 \mathrm{~g} / 1 \mathrm{KH}_{2} \mathrm{PO}_{4}$ could produce ethanol higher that both 0 and $1.0 \mathrm{~g} / \mathrm{l}$ (Fig. 3c). The fermentation with $0.5 \mathrm{~g} / 1 \mathrm{KH}_{2} \mathrm{PO}_{4}$ produced $30.6 \mathrm{~g} / \mathrm{l}$, with a productivity of $0.64(\mathrm{~g} / \mathrm{l}) / \mathrm{h}$, and a yield of $33 \%$ of theoretical yield (Fig. 2c). The fermentation 
Table 2 Ethanol production by PBB511-1 yeast strain in cassava medium containing different concentrations of reducing sugar and nutrient elements (initial $\mathrm{pH} 4.5$, speed $120 \mathrm{rpm}, 45^{\circ} \mathrm{C}$ ).

\begin{tabular}{|c|c|c|c|c|c|c|c|}
\hline \multirow[b]{2}{*}{ Condition } & \multicolumn{3}{|c|}{ Ethanol production after $48 \mathrm{~h}$} & \multicolumn{4}{|c|}{ Ethanol production maximum } \\
\hline & $\begin{array}{l}\text { ethanol } \\
(\mathrm{g} / \mathrm{l})\end{array}$ & $\begin{array}{l}\text { productivity } \\
((\mathrm{g} / \mathrm{l}) / \mathrm{h})\end{array}$ & $\begin{array}{c}\text { yield } \\
\text { (\% of theoretical) }\end{array}$ & $\begin{array}{l}\text { time } \\
\text { (h) }\end{array}$ & $\begin{array}{l}\text { ethanol } \\
(\mathrm{g} / \mathrm{l})\end{array}$ & $\begin{array}{l}\text { productivity } \\
((\mathrm{g} / \mathrm{l}) / \mathrm{h})\end{array}$ & $\begin{array}{c}\text { yield } \\
\text { (\% of theoretical) }\end{array}$ \\
\hline \multicolumn{8}{|l|}{ Sugars $(\mathrm{g} / \mathrm{l})$} \\
\hline 160 & 15.2 & 0.32 & 19 & 54 & 17.3 & 0.32 & 21 \\
\hline 180 & 23.9 & 0.50 & 26 & 72 & 24.3 & 0.34 & 26 \\
\hline 200 & 23.2 & 0.48 & 23 & 54 & 24.6 & 0.46 & 24 \\
\hline \multicolumn{8}{|c|}{$\left(\mathrm{NH}_{4}\right)_{2} \mathrm{SO}_{4}(\mathrm{~g} / \mathrm{l})$} \\
\hline 0 & 14.0 & 0.29 & 15 & 54 & 15.1 & 0.28 & 16 \\
\hline 0.5 & 25.8 & 0.54 & 28 & 48 & 25.8 & 0.54 & 28 \\
\hline 1.0 & 18.4 & 0.38 & 20 & 36 & 19.1 & 0.53 & 21 \\
\hline \multicolumn{8}{|c|}{$\mathrm{KH}_{2} \mathrm{PO}_{4}(\mathrm{~g} / \mathrm{l})$} \\
\hline 0 & 25.9 & 0.54 & 28 & 48 & 25.9 & 0.54 & 28 \\
\hline 0.5 & 30.6 & 0.64 & 33 & 48 & 30.6 & 0.64 & 33 \\
\hline 1.0 & 27.9 & 0.58 & 30 & 48 & 27.9 & 0.58 & 30 \\
\hline \multicolumn{8}{|c|}{$\mathrm{MgSO}_{4} \cdot 7 \mathrm{H}_{2} \mathrm{O}(\mathrm{g} / \mathrm{l})$} \\
\hline 0 & 25.3 & 0.53 & 28 & 48 & 25.3 & 0.53 & 28 \\
\hline 0.5 & 29.7 & 0.62 & 32 & 54 & 30.3 & 0.56 & 33 \\
\hline 1.0 & 27.8 & 0.58 & 30 & 48 & 27.8 & 0.58 & 30 \\
\hline \multicolumn{8}{|c|}{ Yeast extract (g/l) } \\
\hline 0 & 32.2 & 0.67 & 36 & 48 & 32.2 & 0.67 & 36 \\
\hline 1.0 & 36.0 & 0.75 & 39 & 36 & 37.0 & 1.03 & 40 \\
\hline 2.0 & 35.7 & 0.74 & 39 & 48 & 35.7 & 0.74 & 39 \\
\hline
\end{tabular}

without the additional P-source and $1.0 \mathrm{~g} / 1 \mathrm{KH}_{2} \mathrm{PO}_{4}$ produced ethanol at 25.90 and $27.9 \mathrm{~g} / \mathrm{l}$, with productivities of 0.54 and $0.58(\mathrm{~g} / \mathrm{l}) / \mathrm{h}$, and yields of $28 \%$ and $30 \%$ of theoretical yield, respectively (Table 2 ).

At the end of $72 \mathrm{~h}$, the concentration of ethanol of the three cases and the growth rate of yeast cells decreased, since the rate of ethanol production was quite high in the initial 30-54 h of fermentation (data not shown). In the case of using sugar, the medium containing $0.5 \mathrm{~g} / 1 \mathrm{KH}_{2} \mathrm{PO}_{4}$ took more sugar than in other conditions, and at the end of fermentation there was $65 \mathrm{~g} / \mathrm{l}$ sugar remaining, while sugar remained at $75 \mathrm{~g} / \mathrm{l}$ and $73 \mathrm{~g} / \mathrm{l}$ for the medium without P-source and with $1.0 \mathrm{~g} / 1 \mathrm{KH}_{2} \mathrm{PO}_{4}$, respectively.

The influence of magnesium on ethanol production under the basal cassava medium was studied using reducing sugar at $180 \mathrm{~g} / \mathrm{l}, 0.5 \mathrm{~g} / \mathrm{l}\left(\mathrm{NH}_{4}\right)_{2} \mathrm{SO}_{4}$, and $0.5 \mathrm{~g} / 1 \mathrm{KH}_{2} \mathrm{PO}_{4}$, with three concentrations of the Mg-source $\left(\mathrm{MgSO}_{4} \cdot 7 \mathrm{H}_{2} \mathrm{O}\right)$ tested: $0,0.5$, and $1.0 \mathrm{~g} / \mathrm{l}$. The results showed that fermentation with $0.5 \mathrm{~g} / 1$ $\mathrm{MgSO}_{4} \cdot 7 \mathrm{H}_{2} \mathrm{O}$ produced higher ethanol than in the other cases (Fig. 3d). At $48 \mathrm{~h}$ of fermentation, the culture with $0.5 \mathrm{~g} / \mathrm{l} \mathrm{MgSO}_{4} \cdot 7 \mathrm{H}_{2} \mathrm{O}$ produced $29.7 \mathrm{~g} / \mathrm{l}$ ethanol, with a productivity of $0.62(\mathrm{~g} / \mathrm{l}) / \mathrm{h}$ and a yield of $32 \%$ of theoretical yield. On the other hand, the fermentation without Mg-source and with $1.0 \mathrm{~g} / \mathrm{l}$
$\mathrm{MgSO}_{4} \cdot 7 \mathrm{H}_{2} \mathrm{O}$ produced 25.4 and $27.8 \mathrm{~g} / \mathrm{l}$ ethanol, with productivities of 0.53 and $0.58(\mathrm{~g} / \mathrm{l}) / \mathrm{h}$, and yields of $28 \%$ and $30 \%$ of theoretical yield, respectively (Table 2).

In each of these three cases, there was marginal ethanol accumulation at the end of $72 \mathrm{~h}$, but the yeast growth was comparable, growing very quickly during the first $24 \mathrm{~h}$ and remaining constant until the conclusion of the experiment. As for sugar consumption, fermentation with $0.5 \mathrm{~g} / \mathrm{l} \mathrm{MgSO}_{4} \cdot 7 \mathrm{H}_{2} \mathrm{O}$ added was found to consume more sugar than other conditions, and the remaining sugar was $66 \mathrm{~g} / \mathrm{l}$ (Fig. 2d). On the other hand, fermentation without $\mathrm{Mg}$-source and with $1.0 \mathrm{~g} / \mathrm{l} \mathrm{MgSO}_{4} \cdot 7 \mathrm{H}_{2} \mathrm{O}$ added had 75 and $74 \mathrm{~g} / \mathrm{l}$ of sugar remaining, respectively.

The influence of a yeast extract to ethanol production using a basal cassava medium was studied using medium containing $180 \mathrm{~g} / \mathrm{l}$ reducing sugar, $0.5 \mathrm{~g} / \mathrm{l}\left(\mathrm{NH}_{4}\right)_{2} \mathrm{SO}_{4}, 0.5 \mathrm{~g} / 1 \mathrm{KH}_{2} \mathrm{PO}_{4}$, and $0.5 \mathrm{~g} / \mathrm{l}$ $\mathrm{MgSO}_{4} \cdot 7 \mathrm{H}_{2} \mathrm{O}$. The production of ethanol due to fermentation when adding $1.0 \mathrm{~g} / 1$ yeast extract was greater than both with $2.0 \mathrm{~g} / \mathrm{l}$ yeast extract and without yeast extract (Fig. 3e, Fig. 2e). At 48 h, the fermentation with $1.0 \mathrm{~g} / 1$ yeast extract produced $36.0 \mathrm{~g} / \mathrm{l}$ ethanol, with a productivity of $0.75(\mathrm{~g} / \mathrm{l}) / \mathrm{h}$ and yield of $39 \%$ of theoretical yield. The fermentation in medium 

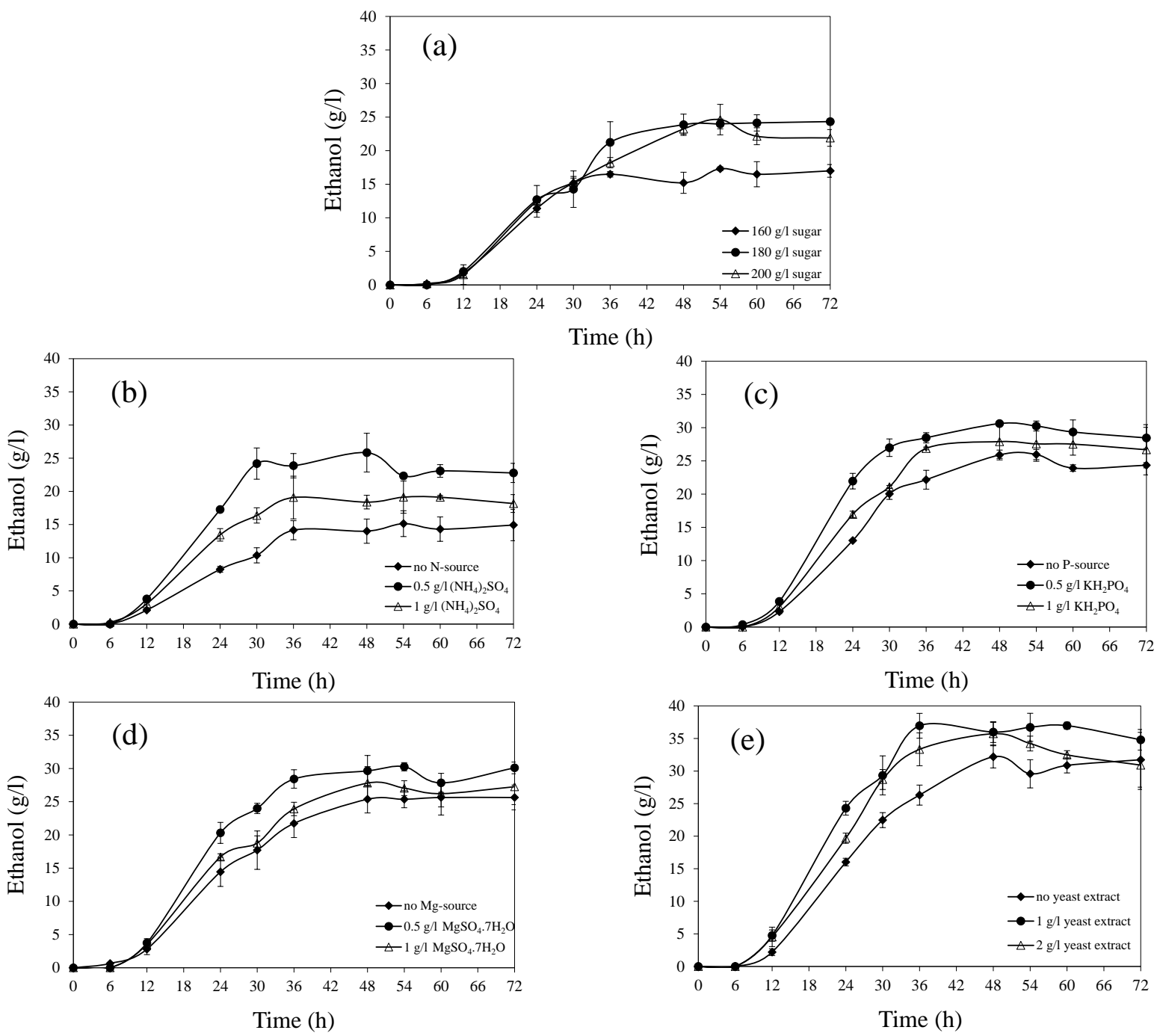

Fig. 3 Comparison of ethanol fermentation under different conditions: (a) sugar concentration, (b) N-source, (c) P-source, (d) Mg-source, and (e) yeast extract.

with $2.0 \mathrm{~g} / \mathrm{l}$ yeast extract produced $35.7 \mathrm{~g} / \mathrm{l}$ ethanol, with a productivity of $0.74(\mathrm{~g} / \mathrm{l} / \mathrm{h} / \mathrm{h}$, and a yield of $39 \%$ of theoretical yield. On the other hand, the fermentation without yeast extract produced $32.8 \mathrm{~g} / \mathrm{l}$ ethanol, with a productivity of $0.67(\mathrm{~g} / \mathrm{l}) / \mathrm{h}$ and a yield of $35 \%$ of theoretical yield (Table 2). It was found that ethanol concentration in these three cases decreased at $72 \mathrm{~h}$ of the fermentation: the fermentation with $1.0 \mathrm{~g} / \mathrm{l}$ yeast extract, $2.0 \mathrm{~g} / \mathrm{l}$ yeast extract, and without yeast extract added produced $34.5 \mathrm{~g} / 1,30.1 \mathrm{~g} / \mathrm{l}$, and $31.7 \mathrm{~g} / \mathrm{l}$ ethanol, respectively. During the first $30 \mathrm{~h}$ of fermentation, the yeast growth in all three conditions was very fast, but after $30 \mathrm{~h}$ the growth decreased. This implied that some of the strains did not survive and may have resulted in an increase in ethanol concentration during the period between 36 and $48 \mathrm{~h}$ and an increase in the fermentation at $45^{\circ} \mathrm{C}$.

Considering the sugar consumption of these three cases, it was found that during the first $36 \mathrm{~h}$ of the fermentation, sugar concentration rapidly decreased and remained constant as the fermentation approached $72 \mathrm{~h}$. The fermentations with $1.0 \mathrm{~g} / \mathrm{l}$ yeast extract, $2.0 \mathrm{~g} / \mathrm{l}$ yeast extract, and without yeast extract added were found to contain 66,70 , and $75 \mathrm{~g} / \mathrm{l}$ sugar, respectively.

Ethanol fermentation was performed at $45^{\circ} \mathrm{C}$ by shaking flask of this yeast strain using $180 \mathrm{~g} / \mathrm{l}$ pure glucose as the substrate. The results showed the highest ethanol production of $45.1 \mathrm{~g} / \mathrm{l}$ at $36 \mathrm{~h}$, with a productivity of $1.25(\mathrm{~g} / \mathrm{l}) / \mathrm{h}$ and a yield of $49 \%$ of 


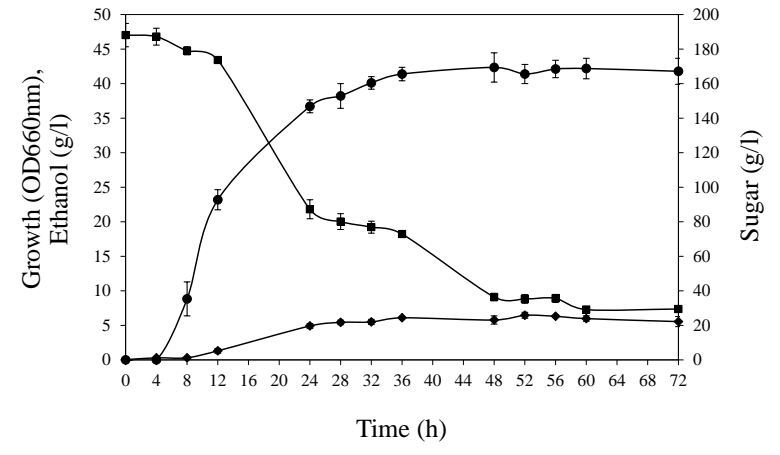

Fig. 4 Ethanol production at $45^{\circ} \mathrm{C}$ of $P$. kudriavzevii PBB511-1 by batch fermentation with agitation speed of $300 \mathrm{rpm}$ and an aeration rate of $0.2 \mathrm{vvm}$ throughout the fermentation. Growth (diamonds), ethanol production (circles), and sugar consumption (squares).

theoretical yield. After the fermentation finished, the remaining glucose concentration was $31 \mathrm{~g} / \mathrm{l}$. The study also looked at cassava starch containing reducing sugar $180 \mathrm{~g} / \mathrm{l}$ as a substrate. The yeast produced $37.0 \mathrm{~g} / \mathrm{l}$ of ethanol at $36 \mathrm{~h}$, with a productivity of $1.03(\mathrm{~g} / \mathrm{l}) / \mathrm{h}$ and a yield of $40 \%$ of theoretical yield. This means that the cassava starch was incompletely converted to glucose. These results imply however that this strain could be able to produce ethanol at high temperature.

From previous studies, the optimized conditions for this strain involved fermentation at room temperature. The results revealed that the ethanol produced was $58.8 \mathrm{~g} / \mathrm{l}$ at $48 \mathrm{~h}$, with a productivity of $1.23(\mathrm{~g} / \mathrm{l}) / \mathrm{h}$ and a yield of $64 \%$ of theoretical yield. After $72 \mathrm{~h}$, the remaining reducing sugar was $4.7 \mathrm{~g} / \mathrm{l}$. Hence this strain could produce ethanol at both room temperature and high temperature.

\section{Ethanol fermentation in a fermenter}

The ethanol fermentation of the strain PBB511-1 by batch fermentation at $45^{\circ} \mathrm{C}$ in basal cassava starch medium composed of $180 \mathrm{~g} / \mathrm{l}$ reducing sugar, $0.5 \mathrm{~g} / \mathrm{l}$ $\left(\mathrm{NH}_{4}\right)_{2} \mathrm{SO}_{4}, 0.5 \mathrm{~g} / \mathrm{K} \mathrm{KH}_{2} \mathrm{PO}_{4}, 0.5 \mathrm{~g} / \mathrm{MgSO} \mathrm{Mg}_{4} \cdot 7 \mathrm{H}_{2} \mathrm{O}$, $1.0 \mathrm{~g} / \mathrm{l}$ yeast extract, with an initial $\mathrm{pH}$ of 4.5 was performed at agitation speed of $300 \mathrm{rpm}$ and an aeration rate of $0.2 \mathrm{vvm}$ throughout the fermentation. The results showed that the maximal ethanol concentration was $42.4 \mathrm{~g} / \mathrm{l}$ at $48 \mathrm{~h}$, with a productivity of $0.88(\mathrm{~g} / \mathrm{l} / \mathrm{h}$ and a yield of $46 \%$ of theoretical yield. The ethanol concentration rapidly increased during the period between 4 and $24 \mathrm{~h}$, after which there was only a slight increase in ethanol, and the sugar consumption sharply decreased during the $12-24 \mathrm{~h}$ period. After this interval, there was a slow ethanol concentration decline. After the fermentation period of $72 \mathrm{~h}$, the sugar remaining in the fermenter was $29 \mathrm{~g} / \mathrm{l}$. The growth of yeast gradually increased between 12 and $24 \mathrm{~h}$ and remained steady until $72 \mathrm{~h}$ (Fig. 4).

\section{DISCUSSION AND CONCLUSIONS}

Samples of 267 yeast strains were analysed to identify effective thermotolerant yeast strains. A total of 33 strains were found to be able to produce ethanol from cassava starch hydrolysate at $45^{\circ} \mathrm{C}$, and 4 of them showed a superb capability in producing ethanol. PBB511-1, TM512-2, CPY514-1, and TG514-2 produced ethanol at 26.2, 26.2, 23.6, and $22.5 \mathrm{~g} / \mathrm{l}$, respectively. The 4 strains were later classified as P. kudriavzevii (I. orientalis), not as well-known as Saccharomyces cerevisiae or Kluyveromyces marxianus, which are often used to produce ethanol. $K$. marxianus, a thermotolerant yeast, has been shown to be able to produce ethanol at temperatures up to $45^{\circ} \mathrm{C}^{9,22,23}$. P. kudriavzevii has been suggested for use in ethanol fermentation since it could be easily found in rice flour ('loog-pang' in terms of Thai traditional fermentation starter) ${ }^{24}$. In addition, there was a study on a yeast growth (I. orientalis DY252) under an air support based batch and fed-batch to use as probiotic source ${ }^{25}$. Furthermore, this yeast was recently studied as a fuel source for biodiesel and bioethanol ${ }^{26-28}$.

This study was aimed to discover an appropriate condition for producing ethanol by the yeast strain PBB511-1 using a cassava starch hydrolysate medium at $45^{\circ} \mathrm{C}$, initial $\mathrm{pH}$ 4.5. The result revealed that cassava starch medium with a concentrated reducing sugar of $180 \mathrm{~g} / 1,0.5 \mathrm{~g} / \mathrm{l}\left(\mathrm{NH}_{4}\right)_{2} \mathrm{SO}_{4}, 0.5 \mathrm{~g} / 1 \mathrm{KH}_{2} \mathrm{PO}_{4}$, $0.5 \mathrm{~g} / \mathrm{MgSO} \mathrm{Mg}_{4} \cdot 7 \mathrm{H}_{2} \mathrm{O}$, and $1.0 \mathrm{~g} / \mathrm{l}$ yeast extract was effective in producing ethanol. Within the first $36 \mathrm{~h}$, it can produce ethanol at $37.0 \mathrm{~g} / \mathrm{l}$, with a productivity of $1.03(\mathrm{~g} / \mathrm{l}) / \mathrm{h}$ and a yield of $40 \%$ of theoretical yield. Recently, Yuangsaard et al ${ }^{29}$ reported that $P$. $k u$ driavzevii DMKU 3-ET15 (isolated from traditional fermented pork sausage) could produce ethanol in a cassava starch hydrolysate medium $\mathrm{pH} 5.0$ composed of $18 \%$ glucose, $0.05 \%\left(\mathrm{NH}_{4}\right)_{2} \mathrm{SO}_{4}, 0.09 \%$ yeast extract, $0.05 \% \mathrm{KH}_{2} \mathrm{PO}_{4}$, and $0.05 \% \mathrm{MgSO}_{4} \cdot 7 \mathrm{H}_{2} \mathrm{O}$. At $45^{\circ} \mathrm{C}$, the yeast produced ethanol $4 \%$ (w/v), with productivity of $1.27(\mathrm{~g} / \mathrm{l}) / \mathrm{h}$ and yield of $42 \%$ of the theoretical yield. Recently a study by Dhaliwal et $\mathrm{al}^{28}$ reported the isolation of $P$. kudriavzevii from sugarcane juice. At $40^{\circ} \mathrm{C}$, the yeast produced $71.9 \mathrm{~g} / \mathrm{l}$ of ethanol and a productivity of $4.0(\mathrm{~g} / \mathrm{l}) / \mathrm{h}$ from sugarcane juice composed of $14 \%$ (w/v) sucrose, $2 \%(\mathrm{w} / \mathrm{v})$ glucose, and $1 \%(\mathrm{w} / \mathrm{v})$ fructose. From the aforementioned reason, $P$. kudriavzevii can be 
a candidate to produce ethanol at high temperature similar to $K$. marxianus.

The batch fermentation was also subjected to $45^{\circ} \mathrm{C}$ growth conditions with agitation speed of $300 \mathrm{rpm}$ and an aeration rate of $0.2 \mathrm{vvm}$ throughout the fermentation period. The results revealed that ethanol was produced at the peak level of $42.4 \mathrm{~g} / \mathrm{l}$ at $48 \mathrm{~h}$, with a productivity of $0.88(\mathrm{~g} / \mathrm{l}) / \mathrm{h}$ and a yield $46 \%$ of the theoretical yield. Under the same conditions, K. marxianus DMKU 3-1042 at $37^{\circ} \mathrm{C}$ produced $6 \%(\mathrm{w} / \mathrm{v})$ of ethanol, with a productivity of $1.3(\mathrm{~g} / \mathrm{l}) / \mathrm{h}$ and a yield of $57 \%$ of theoretical yield ${ }^{9}$. When P. kudriavzevii DMKU 3-ET15 was exposed to $40{ }^{\circ} \mathrm{C}$ with an agitation speed of $300 \mathrm{rpm}$ and an aeration rate of $0.1 \mathrm{vvm}$ throughout the fermentation, it produced a final ethanol of $7 \%(\mathrm{w} / \mathrm{v})$ after $33 \mathrm{~h}$, with a productivity of $2.23(\mathrm{~g} / \mathrm{l}) / \mathrm{h}$ and a yield of $80 \%$ of the theoretical yield ${ }^{29}$. Hence the study confirms that the yeast strain PBB511-1 can be a candidate for ethanol production at high temperatures.

Acknowledgements: This work was completely supported by a grant from the National Research Council of Thailand.

\section{REFERENCES}

1. Nguyen HT, Takenaka N, Bandow H, Maeda Y, de Oliva ST, Botelho MM, Tavares TM (2001) Atmospheric alcohols and aldehydes concentrations measured in Osaka, Japan and Sao Paulo, Brazil. Atmos Environ 35, 3075-83.

2. Zaldivar J, Nielsen J, Olsson L (2001) Fuel ethanol production from lignocellulose: a challenge for metabolic engineering and process integration. Appl Microbiol Biotechnol 56, 17-34.

3. Kádár Zs, Szengyel Zs, Réczey K (2004) Simultaneous saccharification and fermentation (SSF) of industrial wastes for the production of ethanol. Ind Crop Prod 20, 103-10.

4. Kim S, Dale BE (2004) Global potential bioethanol production from wasted crops and crop residues. Biomass Bioenerg 26, 361-75.

5. Nguyen TLT, Gheewala SH, Garivait S (2008) Full chain energy analysis of fuel ethanol from cane molasses in Thailand. Appl Energ 85, 722-34.

6. Papong S, Malakul P (2010) Life-cycle energy and environmental analysis of bioethanol production from cassava in Thailand. Bioresour Tech 101, S112-8.

7. Hillocks RJ, Thresh JM, Bellotti AC (2002) Cassava Biology, Production and Utilization. CABI Publishing, CAB International.

8. Nguyen TLT, Gheewala SH, Garivait S (2007) Energy balance and GHG-abatement cost of cassava utilization for fuel ethanol in Thailand. Energ Pol 35, 4585-96.

9. Limtong S, Sringiew C, Yongmanitchai W (2007)
Production of fuel ethanol at high temperature from sugar cane juice by a newly isolated Kluyveromyces marxianus. Bioresour Tech 98, 3367-74.

10. Eiadpum A, Limtong S, Phisalaphong M (2012) Hightemperature ethanol fermentation by immobilized coculture of Kluyveromyces marxianus and Saccharomyces cerevisiae. J Biosci Bioeng 114, 325-9.

11. Americano da Costa MV, Pasamontes M, Normey-Rico JE, Guzmán JL, Berenguel M (2013) Viability and application of ethanol production coupled with solar cooling. Appl Energ 102, 501-9.

12. AOAC (1990) Official Methods of Analysis of the Association of Official Analytical Chemists, 15th edn, Arlington, VA.

13. AACC (1995) Approved Methods of the American Association of Cereal Chemists, 9th edn, St. Paul, MN.

14. Nelson N (1944) A photometric adaptation of Somogyi method for the determination of glucose. J Biol Chem 153, 375-80.

15. Kurtzman CP, Fell JW (1998) The Yeasts: A Taxonomic Study, 4th edn, Elsevier, Amsterdam.

16. Kurtzman CP, Robnette CJ (1998) Identification and phylogeny of ascomycetous yeasts from analysis of nuclear large subunit (26S) ribosomal DNA partial sequences. Antonie Leeuwenhoek 73, 331-71.

17. Komagata K, Ohmomo S (1984) Quantitative and qualitative analysis of volatile fatty acid alcohol by gas chromatography hitachi. Annual Report, Central Laboratory and Greenhouse Complex, Kasetsart Univ. p 163.

18. Morimura S, Ling ZY, Kida K (1997) Ethanol production by repeated-batch fermentation at high temperature in a molasses medium containing a high concentration of total sugar by a thermotolerant flocculating yeast with improved salt-tolerance. J Ferment Bioeng 3, 271-4.

19. Grubb CF, Mawson AJ (1993) Effects of elevated solute concentration on the fermentation of lactose by Kluyveromyces marxianus Y-113. Biotechnol Lett 15, 621-6.

20. Presscott SC, Dunn CG (1959) Industrial Microbiology, 3rd edn, McGraw-Hill Book Co. Inc., New York.

21. Rose AH, Harrison JS (1993) Yeast Technology. The Yeast. Academic Press, San Diego.

22. Kourkoutas Y, Dimitropoulou S, Kanellaki M, Marchant R, Nigam P, Banat IM, Koutinas AA (2002) High-temperature alcoholic fermentation of whey using Kluyveromyces marxianus IMB3 yeast immobilized on delignified cellulosic material. Bioresour Tech 82, 177-81.

23. Pessani NK, Atiyeh HK, Wilkins MR, Bellmer DD, Banat IM (2011) Simultaneous saccharification and fermentation of Kanlow switchgrass by thermotolerant Kluyveromyces marxianus IMB3: The effect of enzyme loading, temperature and higher solid loadings. Bioresour Tech 102, 10618-24.

24. Limtong S, Sintara S, Suwanarit P, Lotong N (2002) 
Yeast diversity in Thai traditional fermentation starter (loog-pang). Kasetsart J (Nat Sci) 36, 149-58.

25. Shin HT, Lim YB, Koh JH, Kim JY, Baig SY, Lee JH (2002) Growth of Issatchenkia orientalis in aerobic batch and fed-batch cultures. J Microbiol 40, 82-5.

26. Sankh S, Thiru M, Saran S, Rangaswamy V (2013) Biodiesel production from a newly isolated Pichia kudriavzevii strain. Fuel 106, 690-6.

27. Kaur U, Oberoi HS, Bhargav VK, Sharma-Shivappa R, Dhaliwal SS (2012) Ethanol production from alkaliand ozone-treated cotton stalks using thermotolerant Pichia kudriavzevii HOP-1. Ind Crop Prod 37, 219-26.

28. Dhaliwal SS, Oberoi HS, Sandhu SK, Nanda D, Kumar D, Uppal SK (2011) Enhanced ethanol production from sugarcane juice by galactose adaptation of a newly isolated thermotolerant strain of Pichia kudriavzevii. Bioresour Tech 102, 5968-75.

29. Yuangsaard N, Yongmanitchai W, Yamada M, Limtong S (2013) Selection and characterization of a newly isolated thermotolerant Pichia kudriavzevii strain for ethanol production a high temperature from cassava starch hydrolysate. Antonie Leeuwenhoek 103, 577-88. 